\title{
Irfani
}

ISSN 1907-0969 E ISSN 2442-8272

Volume 14 Nomor 2 Desember 2019

Halaman 1-11

http://journal.iaingorontalo.ac.id/index.php/ir

\section{EFEKTIVITAS PENGGUNAAN VIDEO PEMBELAJARAN DALAM MENINGKATKAN KEMAMPUAN MEMPRAKTIKKAN SHALAT BAGI PESERTA DIDIK MI AL-WATHANIYAH KOTA GORONTALO}

\author{
Devikasari A.H. Datau ${ }^{1}$ Muh. Arif ${ }^{2}$ \\ ${ }^{12}$ IAIN Sultan Amai Gorontalo \\ email: devikasaridatau@gmail.com
}

\begin{abstract}
ABSTRAK
Artikel ini membahas tentang penggunaan video pembelajaran di MI al-Wathaniyah Kota Gorontalo. Adapun tujuan penelitian ini adalah untuk meningkatkan kemampuan mempraktikkan shalat bagi peserta didik di MI al-Wathaniyah Kota Gorontalo melalui penggunaan video pembelajaran. Penelitian deskriptif (descriptive research) yaitu jenis penelitian yang memberikan gambaran atau uraian atas sesuatu keadaan sejelas mungkin tanpa ada perlakuan terhadap objek yang diteliti. Hasil penelitian menunjukkan bahwa dengan mengguanakan video pembelajaran sangat efektif dapat meningkatkan kemampuan peserta didik dalam mempraktikkan shalat, video pembelajaran mempermudah guru dalam mengajar juga sangat mempermudah peserta didik dalam menelaah serta membuat peserta lebih cepat memahami gerakan-gerakan serta bacaan'dalam shalat. Penggunaan video pembelajaran khususnya dalam menerapkan materi khususnya pada kemampuan mempratikkan dapat dilihat dapat meningkatkan kemampuan peserta didik dalam mempraktikan shalat dengan adanya suara serta gambar yang dapat mereka lihat secara langsung sehingga merangsang perhatian serta dapat mengasah kemampuan peserta didik dalam mempraktikkan shalat.
\end{abstract}

Kata Kunci: Video Pembelajaran, Mempraktikkan Shalat, dan Peserta Didik

\section{PENDAHULUAN}

Pendidikan merupakan proses holistik/sistemik dan sistematik untuk meningkatkan harkat dan martabat manusia yang memungkinkan potensi diri (sikap, pengetahuan dan keterampilan) berkembang secara optimal. Sejalan dengan itu, kurikulum disusun dengan memperhatikan potensi, bakat, minat serta tingkat perkembangan kecerdasan; intelektual, emosional, sosial, spiritual, dan kinestetik peserta didik. $^{1}$

Dalam peraturan pemerintah Nomor 32 Tahun 2013 tentang perubahan atas peraturan pemerintah Nomor 19 Tahun 2005 bahwa, pembelajaran adalah: proses interaksi antara peserta didik, antara peserta didik dengan pendidik dan sumber belajar

${ }^{1}$ Tedi Priatna, Penelitian Pendidikan, (Bandung: Pustaka Setia, 2012), h. 13. 


\section{Irfani}

ISSN 1907-0969 E ISSN 2442-8272

Volume 14 Nomor 2 Desember 2019

Halaman 1-11

http://journal.iaingorontalo.ac.id/index.php/ir

pada suatu lingkungan belajar. ${ }^{2}$ Terkait dengan beberapa pengertian di atas Pendidikan keagamaan juga merupakan pendidikan yang mempersiapkan peserta didik untuk dapat menjalankan peranan yang menuntut penguasaan pengetahuan khusus tentang ajaran agama yang bersangkutan.

Sedangkan dalam Undang-undang No.2 Tahun 1989 memandang bahwa pendidikan keagamaan bermaksud mempersiapkan peserta didik untuk dapat menjalankan peranannya sebagai pemeluk agama yang benar-benar memadai. Di antara syarat dan prasyarat agar peserta didik dapat menjalankan peranannya dengan baik diperlukan pengetahuan Ilmu Pendidikan Islam. Mengingat ilmu ini tidak hanya menekankan pada teoretis saja, tetapi juga praktis, ilmu pendidikan Islam termasuk ilmu praktis maka peserta didik diharapkan dapat menguasai ilmu tersebut secara penuh baik teoretis maupun praktis, sehingga ia benar-benar mampu memainkan peranannya dengan tepat dalam hidup dan kehidupan.

Pendidikan adalah tanggung jawab bersama berkenaan dengan tanggung jawab ini, maka pendidikan agama di sekolah berarti: suatu usaha yang secara sadar dilakukan guru untuk mempengaruhi siswa dalam rangka pembentukan manusia beragama. Pemberian pengaruh pendidikan agama mempunyai arti ganda, yaitu: pertama, sebagai salah satu sarana agama (Dakwah Islamiyah ) yang diperlukan bagi pengembangan kehidupan keagamaan, dan kedua, sebagai salah satu sarana pendidikkan nasional terutama untuk meningkatkan ketakwaan terhadap Tuhan Yang Maha Esa.

Perkembangan ilmu pengetahuan dan teknologi semakin mendorong upayaupaya pembaharuan dalam pemanfaatan hasil-hasil teknologi dalam proses belajar. Para guru dituntut agar mampu menggunakan alat-alat yang dapat disediakan oleh sekolah, dan tidak tertutup kemungkinan bahwa alat-alat tersebut sesuai perkembangan dengan tuntunan zaman. Guru sekurang-kurangnya dapat menggunakan alat yang murah dan efisien yang meskipun sederhana tetapi merupakan keharusan dalam upaya mencapai tujuan pembelajaran yang diharapkan. Selain mampu menggunakan alat-alat tersedia, guru juga dituntut untuk dapat membuat keterampilan media pembelajaran yang akan digunakannya apabila media tersebut belum tersedia. ${ }^{3}$

Aan Komaria dan Cepi Tratna yang dimaksud efektivitas adalah ukuran yang menyatakan sejauh mana sasaran atau tujuan (kalitas, kuantitas dan waktu) yang telah dicapai. Efektivitas dibuat adalah penilaian yang dibuat sehubungan dengan prestasi individu, kelompok organisasi, makin dekat pencapaian prestasi yang diharapkan, supaya lebih efektif hasil penilaiannya. ${ }^{4}$ Berdasarkan beberapa pendapat ahli, dapat disimpulkan bahwa efektivitas ialah suatu keadaan dan ukuran sejauh mana manfaat tercapainya tujuan yang telah tercapai.

\footnotetext{
${ }^{2}$ Peraturan Pemerintah Nomor 32 Tahun 2013 tentang Perubahan atas Peraturan Pemerintah Nomor 19 Tahun 2005, h. 35.

${ }^{3}$ Asnawir dan Usman, Media Pembelajaran, (Jakarta: Ciputat Pers, 2002), h. 1.

${ }^{4}$ Aan Komaria dan Cepi Tratna, Visionary Leadership Menuju Sekolah Efektif, (Bandung: Bumi Akasara, 2005), h. 34.
} 


\section{Irfani}

ISSN 1907-0969 E ISSN 2442-8272

Volume 14 Nomor 2 Desember 2019

Halaman 1-11

http://journal.iaingorontalo.ac.id/index.php/ir

Media pembelajaran merupakan salah satu komponen pembelajaran yang mempunyai peranan penting dalam kegiatan pembelajaran. Pemanfaatan media seharusnya merupakan bagian yang harus mendapat perhatian oleh guru atau fasilitator dalam setiap kegiatan pembelajaran. Oleh karena itu guru atau fasilitator perlu mempelajari bagaimana menetapkan media pembelajaran agar dapat mengefektifkan pencapaian tujuan pembelajaran dalam proses pembelajaran. ${ }^{5}$ Hal ini disimpulkan bahwa pengelolaan media pembelajaran merupakan suatu penataan atau kegiatan dalam proses menuntut ilmu.

Dalam proses pembelajaran, media telah dikenal sebagai alat bantu mengajar yang seharusnya digunakan oleh guru, namun kerap kali terabaikan. Tidak digunakannya media dalam proses pembelajaran pada umumnya disebabkan oleh berbagai alasan seperti waktu persiapan mengajar terbatas, sulit mencari media yang tepat, biaya tidak tersedia atau alasan lain. Demikian halnya dengan pembelajaran yang terkadang terdapat beberapa guru tidak menggunakan media dalam proses pembelajaran. ${ }^{6}$

Media dalam proses pembelajaran cenderung diartikan dalam grafis, photografis, atau elektronis untuk menangkap, memproses, dan menyusun kembali informasi visual atau verbal. Media pendidikan digunakan dalam rangka komunikasi dan interaksi antara guru dan siswa dalam proses pembelajaran. Media pembelajaran dapat memperjelas penyajian pesan dan informasi sehingga dapat meningkatkan dan memperlancar proses dan hasil dari pembelajaran. ${ }^{7}$

Media video pembelajaran dapat digolongkan kedalam jenis media Audio Visual Aids (AVA) atau media yang dapat dilihat dan didengar oleh para peserta didik maupun pendidik. Media audio motion visual (media audio visual gerak) yakni media yang mempumyai suara, ada gerakan dan bentuk objeknya yang terlihat. Informasi yang disajikan melalui media berbentuk dokumen yang hidup, dapat dilihat pada layar monitor atau ketika diproyeksikan di layar lebar melalui projector dapat didengar suaranya dan dapat dilihat (video atau animasi) tentang bacaan dan gerakan dalam shalat.

Shalat adalah rukun Islam yang paling pertama setelah kalimat syahadat. Selain itu shalat juga merupakan ibadah yang paling baik dan sempurna di sisi Allah swt. Shalat tersusun dari berbagai jenis ibadah, seperti berzikir kepada Allah swt., membaca alQur'an, menghadap Allah swt., rukuk, sujud, berdoa, bertasbih dan bertakbir. Shalat adalah tiang agama bagi umat Islam serta bagaikan ibadah-ibadah badaniyah lainnya yang merupakan ajaran para Nabi. ${ }^{8}$

Berdasarkan observasi awal di MI al-Wataniyah Kota Gorontalo menunjukan bahwa media pembelajaran yang digunakan hanya sederhana. Kalaupun ada guru yang menggunakan media pembelajaran maka media yang akan digunakan dalam proses pembelajaran, guru hanya memilih salah satu media yang digunakan dalam kelas.

\footnotetext{
${ }^{5} \mathrm{http}: / /$ edu-articles.com/mengenal-media-pembelajaran/htm diakses tgl 10 mar 2018.

${ }^{6}$ Wina Sanjaya, Strategi Pembelajaran, (Jakarta: Kencana Predana Media Group, 2008), h. 164.

${ }^{7}$ Anissatul Mufarokah, Strategi Belajar Mengajar, (Yogyakarta: Teras, 2009), h.104.

${ }^{8}$ Saleh al-Fauzan, Fiqih Sehari-Hari, Penerjemah: Abdul Hayyie al-Kattani, Ahmad Ihwani dan Budiman Mushtofa, (Cet.1; Jakarta: Gema Insani Press, 2005), h. 58.
} 


\section{Irfani}

ISSN 1907-0969 E ISSN 2442-8272

Volume 14 Nomor 2 Desember 2019

Halaman 1-11

http://journal.iaingorontalo.ac.id/index.php/ir

\section{KAJIAN YANG RELEVAN}

Setelah membaca dan mempelajari beberapa karya ilmiah sebelumnya, unsur relevannya dengan penelitian yang dilakukan adalah sama-sama mengguanakan media video pembelajaran. Adapun penelitian tersebut adalah penelitian yang dilakukan oleh Thomas Adi Tri Nugroho dari Universitas Negeri Yogyakarta 2015, Jurusan Pendidikan Pra Sekolah dan Sekolah Dasar yaitu dengan judul "Pengaruh Penggunaan Media Video Pembelajaran terhadap Keterampilan Proses IPA dan Hasil Belajar IPA pada Siswa Kelas V SD Negeri Rejowinangun 1 Yogyakarta. ${ }^{9}$ Selain itu Wahyu Rifqi Silvia dari Universitas Negeri Malang Jurusan Kependidikan Sekolah Dasar dan Prasekolah yaitu dengan judul "Pengaruh Penggunaan Media Video Pembelajaran terhadap Hasil Belajar IPA Siswa Kelas IV SDN Kupang Kabupaten Sidoarjo.

\section{METODOLOGI PENELITIAN}

Jenis penelitian yang digunakan adalah penelitian kualitatif, yaitu suatu penelitian yang ditujukan untuk mendeskripsikan dan menganalisis fenomena, peristiwa, aktivitas, sosial, sikap, kepercayaan, persepsi, pemikiran orang secara individual atau secara kelompok. ${ }^{10}$

Menurut Bogdan dan Taylor, bahwa metode kualitatif sebagai prosedur penelitian yang menghasilkan data deskriptif berupa kata-kata tertulis atau lisan dari orang-orang dan perilaku yang dapat diamati. Sejalan dengan definisi tersebut, Kirl dan Miller mendefinisikan bahwa penelitian kualitatif adalah tradisi tertentu dalam ilmu pengetahuan sosial yang secara fundamental bergantung dari pengamatan pada manusia baik dalam kawasannya maupun dalam peristilahannya. ${ }^{11} \mathrm{Jadi}$ dengan demikian dalam penelitian kualitatif lebih menonjolkan pada upaya pengolahan data dalam bentuk katakata yang bersifat prediktif, interpretative, dan factual. Penelitian ini sebagai jenis penelitian lapangan dan termasuk dalam penelitian murni atau pure research yakni penelitian ini dilakukan dengan melakukan penelitian lapangan secara langsung.

\section{HASIL PENELITIAN DAN PEMBAHASAN}

\section{A. Deskripsi Hasil Penelitian}

1. Penggunaan Video Pembelajaran

Rekaman gambar atau televisi merupakan bagian dari video, dengan kata lain video merupakan tayangan gambar yang bergerak yang disertai dengan suara. Media ini dapat menambah minat siswa karena siswa dapat menyimak sekaligus melihat gambar kemampuan video melukiskan gambar hidup dan suara yang memberikan daya tarik

\footnotetext{
${ }^{9}$ http://eprints.uny.ac.id/16596/1/Skripsi_Thomas\%20Adi\%20Tri\%20Nugroho. diakses pada tgl 15 Mar 2018.

${ }^{10}$ Nana Syodih Syukmadinah, Metode Penelitian Pendidikan, (Bandung: Remaja Rosdakarya, 2013), h. 60 .

${ }^{11}$ Lexy J Moleong, Metodologi Penelitian Kualitatif, (Bandung: Remaja Rosdakarya, 2013), h. 4.
} 


\section{Irfani}

ISSN 1907-0969 E ISSN 2442-8272

Volume 14 Nomor 2 Desember 2019

Halaman 1-11

http://journal.iaingorontalo.ac.id/index.php/ir

tersendiri. Video pembelajaran adalah suatu media yang dirancang secara sistematis dengan berpedoman keapada kurikulum yang berlaku dan dalam pengembangannya mengaplikasikan prinsip-prinsip pembelajaran sehingga program tersebut memungkinkan peserta didik mencermati materi pelajaran dengan mudah dan menarik. Secara fisik video pembelajaran dikemas dalam kaset dan disajikan dengan menggunakan peralatan VTR atau VCD player serta TV monitor.

Berdasarkan pengamatan, guru agama tepatnya pada Mata Pelajaran Fikih ini tidak sering menggunakan video pembelajaran di setiap materi yang diajarkan, meskipun dengan menggunakan video pembelajaran akan lebih mempermudah guru serta peserta didik dalam pembelajaran akan tetapi guru masih kurang dalam menerapkan media tersebut. Video pembelajaran digunakan hanya pada beberapa materi ajar atau mata pelajaran tertentu dan pada waktu tertentu pula.

Hal tersebut di atas membuat peserta didik kurang mengetahui tentang bagaimana tatacara serta bacaan-bacaan dalam shalat meskipun baru pada jenjang awal akan tetapi kemampuan peserta didik dalam mempraktikkan shalat harus lebih diasah sejak usia dini agar ketika mereka mulai ikut shalat dzuhur mereka dapat mengerjakan shalat dengan benar. Karena menurut hasil dari peneliti bahwa yang mana peserta didik ini belum diikut sertakan pada saat shalat dzuhur berjamaah yang dikarenakan oleh beberapa faktor yaitu (1) Karena dikhawatirkan pada saat shalat mereka akan main-main sehingga mengganggu kakak-kakak kelas mereka dan (2) Jam pulang mereka tepat pukul 12:00 jadi itulah beberapa faktor yang mempengaruhi peserta didik Kelas III belum ikut serta dalam shalat berjamaah, kemampuan mereka terhadap tatacara mempraktikkan shalat masih rendah. Hal ini dapat dilihat hasil wawancara dengan Indarmi, S.Pd., mengatakan bahwa:

Untuk tatacara shalat peserta didik sudah cukup mengerti terutama gerakan dalam shalat peserta didik sebagian besar sudah lancar akan tetapi kalau dalam bacaanbacaannya mereka masih sangat sedikit yang mengetahuinya". ${ }^{12}$

Berdasarkan hasil wawancara di atas maka dapat dilihat kemampuan peserta didik dalam mempraktikkan shalat masih sangat minim, dan tentunya selain itu harus perlu diterapkan media yang dapat membuat siswa mudah dalam memahami serta mencermati serta mengerti apa saja maksud dan tujuan dari guru dalam menerapkan materi tersebut. Karena seperti yang penulis ketahui rata-rata dari peserta didik baik itu dari tingkat SMA, SMP, SD/MI pasti akan merasa bosan jika digunakan media atau strategi yang membosankan.

Dan berdasarkan hasil wawancara bersama salah seorang guru Indarmi, S.Pd., menyatakan bahwa:

"Kalau dalam gerakan shalat sebagian besar bahkan semua dari mereka sudah mengetahuinya karena kebanyakan dari mereka melihat dari bahkan ada beberapa yang sering shalat dengan orang tua mereka. Jadi untuk gerakan dalam shalat kiranya tidak ada yang tidak mengetahuinya, hanya saja untuk gerakan shalat mereka belum mengetahui seperti yang mana yang namanya rukuk, i'tidal mereka masih belum tahu tapi dapat mempraktikkannya. Dari sebagian besar

\footnotetext{
${ }^{12}$ Indarmi, S.Pd., Guru MI al-Wathaniyah Kota Gorontalo, Wawancara, 13 Februari 2019.
} 


\section{Irfani}

ISSN 1907-0969 E ISSN 2442-8272

Volume 14 Nomor 2 Desember 2019

Halaman 1-11

http://journal.iaingorontalo.ac.id/index.php/ir

peserta didik belum mengetahui tentang bacaan-bacaan dalam shalat. Ada dari mereka tapi hanya beberapa orang itupun tidak semuanya hanya digerakan bagian-bagian seperti: Bacaan al-Fatihah, rukuk, dan sujud"13

Berdasarkan hasil wawancara tersebut dapat dipahami bahwa yang mana kemampuan peserta didik dalam mempraktikkan shalat masih perlu ditingkatkan yaitu dengan menggunakan media yang menarik perhatian peserta didik serta mempermudah mereka dalam mempraktikkan shalat.

2. Kemampuan Peserta Didik dalam Mempraktikkan Shalat

Pada dasarnya video pembelajaran menjadi salah satu pilihan bagi guru dalam mengatasi permasalahan-permasalahan yang ada dan untuk mengajar kepada peserta didik terutama dalam hal mempraktikkan shalat, maka tampak dengan menggunakan video pembelajaran dengan adanya gambar yang disertai dengan suara dapat meningkatkan kemampuan peserta didik dalam mempraktikkan shalat yang di tampilkan oleh guru melalui video. Maka dari itu dengan mengguanakan video pembelajaran dapat mengefektifkan serta meningkatkan kemampuan peserta didik dalam mempraktikkan shalat, dapat dilihat dari hasil wawancara bersama Ibu Indarmi, S.Pd., Guru MI alWathaniyah Kota Gorontalo tentang bagaimana video pembelajaran sebagaimana dikatakan bahwa:

"Menurut saya video pembelajaran ini sangat efektif digunakan di dalam kelas apalagi untuk peserta didik Kelas III yang mana anak-anak pada zaman sekarang paling suka dengan menonton jadi ketika digunakan video pembelajaran ini mereka sangat antusias di dalamnya. Dengan menggunakan video pembelajaran ini sangat mempermudah guru dalam menerapkan materi kepada peserta didik terutama dalam mempraktikkan shalat karena selain mereka dapat melihat gambar mereka juga langsung mendengarkan suara dari gambar yang mereka lihat. Video pembelajaran ini juga tentunya sangat membantu peserta didik dalam belajar terutama dalam mempraktikkan shalat yang mana mereka memerlukan contoh yang real (nyata) supaya mereka dapat lebih mudah dalam mempraktikkannya dan memang benar setelah dilakukannya uji coba kemampuan peserta didik jauh lebih meningkat kemampuan mereka dalam mempraktikkan shalat baik itu dari gerakannya maupun bacaannya." 14

Berdasarkan hasil wawancara di atas dapat digambarkan bahwa dengan menggunakan video pembelajaran kemampuan mempraktikkan shalat bagi peserta didik meningkat, yang mana dengan adanya gambar dan suara yang lebih menarik perhatian serta memudahkan mereka dalam mencermati materi yang disajikan lewat video pembelajaran.

Melalui hasil wawancara yang dilakukan dengan salah seorang peserta didik di MI al-Wathaniyah Kota Gorontalo, Putri Nazlah Ulfa Basalamah mengatakan bahwa:

\footnotetext{
${ }^{13}$ Indarmi, S.Pd., Guru MI al-Wathaniyah Kota Gorontalo, Wawancara, 14 Februari 2019.

${ }^{14}$ Indarmi, S.Pd., Guru MI al-Wathaniyah Kota Gorontalo, Wawancara, 13 Februari 2019.
} 


\section{Irfani}

ISSN 1907-0969 E ISSN 2442-8272

Volume 14 Nomor 2 Desember 2019

Halaman 1-11

http://journal.iaingorontalo.ac.id/index.php/ir

"Saya sangat suka karena dengan melihat video secara langsung lebih mudah untuk mengetahui gerakan serta bacaan dalam shalat dan tidak cepat bosan di dalam kelas karena gambarnya menyenangkan juga sangat menarik ${ }^{\text {‘ } 15}$

Berdasarkan penjelasan tersebut tampak guru dalam menyajikan video pembelajaran di dalam kelas berupa LCD, laptop dan speaker sangat membantu peserta didik dalam mempraktikkan shalat di depan kelas/mushalla. Karena dengan menggunakan video pembelajaran juga sangat mempermudah peserta didik untuk mengetahui gerakan-gerakan shalat.

Selanjutnya menurut siswa yang lainnya yaitu Nasya Ananda Sukri siswa di MI al-Wathaniyah menyatakan bahwa:

"Nasya suka dengan videonya dan mudah menghapalkan bacaannya karena

Nasya mudah menghapal dengan cara mendengar"

Salah satu yang perhatian bahwa dari sekian banyaknya peserta didik dengan cara belajar yang berdeda-beda, ada yang hanya dengan membaca mereka langsung dapat mencermati materi tersebut, ada juga dengan cara mendengar dan lain sebagainya dan salah satu dari peserta didik tersebut sangat menyukainya bahkan kemampuannya jauh lebih meningkat dari yang sebelumnya.

Nurain Saleh yaitu salah seorang peserta didik yang diwawancarai, ia mengatakan bahwa: "saya suka dengan video shalatnya karena bisa melihat gambar serta bagamana cara gerakan-gerakan dalam shalat"17

Berdasarkan wawancara tersebut dapat digambarkan bahwa video pembelajaran sangat berdampak positif dalam meningkatkan kemampuan mempraktikkan shalat bagi peserta didik. Hal ini dapat dilihat setelah diterapkannya video pembelajaran, mereka bukan hanya sekedar suka akan tetapi kemampuan merekapun meningkat.

Dari penjelasan beberapa informan di atas dapat katakan bahwa dengan menggunakan video pembelajaran itu sangat membantu peserta didik dalam meningkatkan kemampuan mempraktikkan shalat, karena dengan video pembelajaran juga dapat mendorong atau membangitkan keinginan peserta didik dalam belajar.

Berdasarkan hasil wawancara dengan Indarmi, S.Pd., MI al-Wathaniyah Kota Gorontalo mengatakan bahwa:

"Setelah saya terapkan video pembelajaran peserta didik jauh lebih mengerti bagaimana cara memperagakan shalat serta bacaan-bacaan dalam shalat, artinya kemampuan mereka sudah jauh lebih meningkat dari yang sebelum diterapkan video pembelajaran. Mereka juga sangat antusias bahkan pada saat berlangsungnya video pembelajaran mereka mengikuti bacaan-bacaan shalat artinya mereka sebelumnya pernah menghapal akan tetapi kadang lupa jadi di samping video sedang berlangsung mereka juga sembari mengasa hapalan yang

\footnotetext{
${ }^{15}$ Putri Nazlah Ulfa Basalamah, Siswa Kelas III MI al-Wathaniyah Kota Gorontalo, Wawancara, 13 Februari 2019.

${ }^{16}$ Nasya Ananda Sukri, Siswa Kelas III MI al-Wathaniyah Kota Gorontalo, Wawancara, 13 Februari 2019.

${ }^{17}$ Nailah, Siswa Kelas III MI al-Wathaniyah Kota Gorontalo, Wawancara, 13 Februari 2019.
} 


\section{Irfani}

ISSN 1907-0969 E ISSN 2442-8272

Volume 14 Nomor 2 Desember 2019

Halaman 1-11

http://journal.iaingorontalo.ac.id/index.php/ir

sebelumnya pernah dihapalkan. Video ini sangat membantu memudahkan guru dan peserta didik dalam menerapkan serta mempelajari tatacara shalat." 18

Jadi dengan digunakan video pembelajaran sangat mempermudah guru maupun peserta didik dalam mengajarkan serta mempraktikkan shalat, hal ini tentunya juga telah meningkatkan kemampuan peserta didik dalam mempraktikkan shalat, video pembelajaran sangat berdampak positif baik bagi guru maupun peserta didik.

Tabel I

Hasil Pengamatan Video Pembelajaran

\begin{tabular}{|c|l|c|c|}
\hline No. & \multicolumn{1}{|c|}{ Indikator } & Pengamatan & Ket. \\
\hline a. & Laptop & & \\
\hline b. & LCD & & \\
\hline c. & Speaker & & \\
\hline
\end{tabular}

Hasil olahan pengamatan 2019

Video pembelajaran yang digunakan sangat mengarah kepada peserta didik karena tersampainya materi, selain itu juga dapat meningkatkan kemampuan shalat bagi peserta didik, dan dengan menggunakan video pembelajaran dapat mempermudah guru dalam mengajar, lebih mudah membuat peserta didik paham dengan tatacara serta prosedur yang disampaikan.

B. Kendala dan Solusi Penggunaan Video Pembelajaran dalam Kemampuan Mempraktikkan Shalat bagi Peserta Didik di MI al-Wathaniyah Kota Gorontalo

Video pembelajaran ialah suatu alat pembelajaran yang digunakan MI alWathaniyah dan itu sangat membantu guru dalam mengajar serta menyampaikan maksud dan tujuan yang ingin dicapai dan tentunya juga sangat membantu peserta didik dalam belajar terutama dalam mempraktikkan shalat. Video pembelajaran ini sangat mudah untuk ditangkap maksud dan tujuannya oleh peserta didik karena dengan mereka melihat gambar serta mendengrkan suaranya sangat mempermudah mereka dalam melihat bahkan mendengarkan secara rill bagaimana cara menghapal gerakan serta bacaan-bacaan dalam shalat. Akan tetapi itu tidak mudah untuk menerapkan dan memanfaatkan video pembelajaran, berikut ini wawancara yang akan penulis paparkan untuk membahas tentang hambatan-hambatan dalam menerapkan video pembelajaran.

1. Fasilitas pendukung kurang

Kreatifnya guru dalam memanfaatkan video pembelajaran sangat bagus sehingga membuat peserta didik sangat antusias untuk mengikuti kegiatan pembelajaran agar tujuan pembelajaran dapat tercapai. Guru akan melakukan berbagai cara untuk mencegah agar peserta didik tidak merasa bosan.

Pastinya dalam pemanfaatan suatu media harus membutuhkan beberapa alat/bahan yang di butuhkan dan harus disiapkan karena setiap media yang digunakan tentunya berasal dari suatu benda atau alat tertentu.

Berdasarkan pengamatan penulis bahwa kendala yang dihadapi guru dalam menggunakan video pembelajaran sebagaimana yang dikemukakan guru bahwa LCD,

\footnotetext{
${ }^{18}$ Indarmi, S.Pd., Guru MI al-Wathaniyah Kota Gorontalo, Wawancara, 13 Februari 2019.
} 


\section{Irfani}

ISSN 1907-0969 E ISSN 2442-8272

Volume 14 Nomor 2 Desember 2019

Halaman 1-11

http://journal.iaingorontalo.ac.id/index.php/ir

laptop di sekolah masih sangat terbatas sehingga ketika guru akan menerapkan video pembelajaran terkadang masih menggunakan laptop pribadi." ${ }^{, 19}$

Wawancara yang penulis lakukan dengan salah satu guru MI al-Wathaniyah Kota Gorontalo dapat terlihat bahwa hambatan yang dihadapi dalam menerapkan video pembelajaran adalah dari segi fasilitas sekolah yang masih terbatas. Jadi yang menjadi hambatan untuk guru dalam menerapkan video pembelajaran ini adalah dari segi fasilitas sekolah yang kurang memadai.

2. Penggunaan arus listrik cukup tinggi

Pada saat menerapkan video pembelajaran tentunya menggunakan LCD, Laptop dan juga speeker untuk pengeras suara, dan pada saat itu pasti akan menguras cukup banayak tegangan listrik yang mengakibatkan liastiknya padam dalam beberapa waktu kemudian setelah berlangsungnya materi dengan menggunakan video pembelajaran. Jadi dapat diketahui seperti yang dikatakan oleh salah seorang guru yang ada di MI al-Wathaniyah Kota Gorontalo bahwa:

"Listrik di sekolah ini pada saat tertentu akan padam, apalagi jika dalam menggunakan arus listrik yang berlebihan pada saat yang bersamaan ketika sedang mengajar, kemudian kipas angin sedang terpasang belum lagi jika sedang menggunakan laptop ketika para guru sedang mengerjakan tugasnya dan lainlain. Hal itu sangat mengakibatkan tegangan arus listrik yang cukup besar". ${ }^{20}$

Berdasarkan wawancara di atas bahwa jika menggunakan listrik yang berlebihan akan mengakibatkan padamnya arus listrik, artinya arus listrik menjadi salah satu dari hambatan dalam penggunaan video pembelajaran jadi ketika video sedang diterapkan jika ada beberapa alat elekrtonik lainnya yang sedang digunakan maka tidak menutup kemungkinan bahwa listrik yang ada di sekolah dengan seketika akan padam yang dikarenakan penggunaan alat elektronik yang melebihi batas pemakaian.

Tabel II

\begin{tabular}{|c|l|l|}
\hline No. & \multicolumn{1}{|c|}{ Aspek yang diobservasi } & Hasil Pengamatan \\
\hline 1. & Fasilitas Pendukung Kurang & \\
\hline 2. & Pemakaian Arus Listrik Cukup tinggi & \\
\hline
\end{tabular}

Secara terstruktur kendala yang dialami guru dalam menerapkan video pembelajaran dalam Kelas III MI al-Wathaniyah Kota Gorontalo.

\section{Solusi Pemanfaatan Video Pembelajaran di Kelas III MI al-Wathaniyah Kota Gorontalo}

Setiap permasalahan yang terjadi di dalam proses pembelajaran diperlukan penyikapan di dalam bentuk perumusan usaha untuk memecahkan masalah atau memberikan solusi dari masalah yang didapati oleh guru Kelas III MI al-Wathaniyah Kota Gorontalo, yang sangat berhubungan dengan video pembelajaran.

Adapun solusi yang dilakukan untuk mengatasi kendala yang didapati ketika menerapkan video pembelajaran adalah melengapi fasilitas pendukung yang masih

\footnotetext{
${ }^{19}$ Indarmi, S.Pd., Guru MI al-Wathaniyah Kota Gorontalo, Wawancara, 13 Februari 2019.

${ }^{20}$ Ramlah Harmain, S.Ag., Guru MI al-Wathaniyah Kota Gorontalo, Wawancara, 13 Februari 2019.
} 


\section{Irfani}

ISSN 1907-0969 E ISSN 2442-8272

Volume 14 Nomor 2 Desember 2019

Halaman 1-11

http://journal.iaingorontalo.ac.id/index.php/ir

kurang di sekolah. Sebagaimana diungkapkan oleh guru Kelas III MI al-Wathaniyah Kota Gorontalo bahwa:

Untuk sementara waktu para guru menggunakan secara bergantian, jadi ketika salah satu guru ingin menggunakan LCD tersebut mereka harus memberi tahu dan melakukan peminjaman melalui Tata Usaha Madrasah berdasarkan prosedur penggunaan milik madrasah. Sehingga penggunaannya tidak menimbulkan masalah yang pada gilirannya semua guru dapat menggunakannya ketika mereka membutuhkan. ${ }^{21}$

Seiring dengan hal ini Kepala Madrasah menyatakan bahwa akan berusaha untuk mengadakan fasilitas yang kurang dengan merundingkannya dengan Ketua Yayasan, sebagaimana hasil perbincangannya disampaikan bahwa:

"Akan diadakan perancangan perbaikan jaringan listrik, pengadaan laptop tambahan, LCD player, layar scren jadi jika diperlukan maka semua barang atau alat yang dibutuhkan telah tersedia."22

\section{KESIMPULAN}

Dengan memanfaatkan video pembelajaran sangat efektif serta dapat meningkatkan kemampuan peserta didik dalam mempraktikkan shalat, video pembelajaran mempermudah guru dalam mengajar juga sangat mempermudah peserta didik dalam menelaah serta membuat peserta didik lebih cepat memahami gerakangerakan serta bacaan'dalam shalat. Penggunaan video pembelajaran khususnya dalam menerapkan materi shalat dapat meningkatkan kemampuan peserta didik dalam mempraktikan shalat. Pemanfaatan video pembelajaran mengarah pada peserta didik tersampainya isi pembelajaran kepada peserta didik secara langsung, selain itu juga dapat meningkatkan kemampuan peserta didik dalam mempraktekkan shalat serta mempermudah guru dalam menyampaikan materi sehingga peserta didik dapat mengerti sertá memahami maksud dari diterapkannya materi serta tatacara mempratikkan shalat, dan tercapainya maksud dan tujuan dari pembelajaran tersebut. Kendala yang dihadapi guru dalam menerapkan video pembelajaran sebagaimana yang dikemukakan oleh guru bahwa kendala yang dihadapi adalah kurangnya fasilitas di sekolah seperti laptop, LCD, serta tegangan listrik yang masih rendah sehingga terkadang saat menggunakan video pembelajaran harus menggunakan laptop sendiri. Adapun solusi yang dilakukan dalam mengatasi kendala penggunaan video pembelajaran adalah dengan cara melengkapi fasilitas pendukung serta memperbaiki fasilitas yang bermasalah seperti listrik yang terkadang masih sering padam dikarenakan faktor tertentu. Sehingga ketika dibutuhkan semua fasilitas yang dibutuhkan telah tersedia.

\footnotetext{
${ }^{21}$ Indarmi, S.Pd., Guru MI al-Wathaniyah Kota Gorontalo, Wawancara, 13 Februari 2019.

${ }^{22}$ Ismail Muhammad Haluti, M.Pd., Kepala MI al-Wathaniyah Kota Gorontalo, Wawancara, 13
} Februari 2019. 


\section{Irfani}

ISSN 1907-0969 E ISSN 2442-8272

Volume 14 Nomor 2 Desember 2019

Halaman 1-11

http://journal.iaingorontalo.ac.id/index.php/ir

\section{DAFTAR PUSTAKA}

az-Zaghabi. Abdul Malik Muhammad. Malang Nian Orang yang Tidak Shalat. Jakarta: Pustaka al-Kautsar, 2001.

Asnawir dan Usman, Media Pembelajaran. Jakarta: Ciputat Pers, 2002.

al-Bani, Nashiruddin. Ringkasan Shahih Muslim. Diterjemahkan oleh Elly Latifah Saleh al-Fauzan.

al-Fauzan, Saleh. Fiqih Sehari-Hari. Diterjemahkan oleh Abdul Hayyie al-Kattani http://edu-articles.com/mengenal-media-pembelajaran/htm diakses 10 Maret 2018. http://eprints.uny.ac.id/16596/1/Skripsi_Thomas\%20Adi\%20Tri\%20Nugroho. Diakses pada tgl 15 Mar 2018.

http://karya-ilmiah.um.ac.id/index.php/KSDP/article/view/21315. diakses 15 Mar 2018.

http://pasca.um.ac.id/comprences/index.php/sntepnpdas/article/view/849. diakses 10 Agustus 2019.

Ihwani, Ahmad. dan Mushtofa Budiman, Cet.1; Jakarta: Gema Insani Press, 2005.

Khalil, Mustafa. Berjumpa Allah dalam Shalat. Jakarta: Pustaka Zahara, 2004.

Komaria, Aan. dan Tratna Cepi, Visionary Leadership menuju Sekolah Efektif, Bandung: Bumi Akasara, 2005.

Masykur, Abdurrahman. dkk., Kupas Tuntas Tata Cara Shalat dan Hikmahnya. Jakarta: Erlangga, 2006.

Moleong, Lexy J. Metodologi Penelitian Kualitatif. Bandung: Remaja Rosdakarya, 2013.

Muhammad, Teungku. dan as-Shidiqiey Hasbi. Pedoman Shalat. Semarang: Pustaka Rizki Putra, 2000.

Mufarokah, Anissatul. Strategi Belajar Mengajar. Yogyakarta: Teras, 2009.

Peraturan Pemerintah Nomor 32 Tahun 2013 tentang Perubahan atas Peraturan Pemerintah Nomor 19 Tahun 2005.

Priatna, Tedi, Pengantar Pendidikan. Bandung: Pustaka Petia, 2012.

Razak, Nasarudin. Ibadah Shalat menurut Sunnah Rasulullah. Bandung: al Ma'arif, 1993.

Rifa'i, Moh. Risalah Tuntunan Shalat Lengkap, Semarang: Karya Toha, 2006.

Sabiq, Sayyid. Fiqh Sunnah. Jakarta: Pena Pundi Aksara, 2004.

Sanjaya Wina, Strategi Pembelajaran. Jakarta: Kencana Predana Media Group, 2008.

Sayyid, Sabiq. Fiqh Sunnah. Jakarta: Pena Pundi Aksara, 2004.

Sugiono, Metode Penelitian Pendidikan. Bandung: Alfabeta, 2010.

Syukmadinah, Nana Syaodih, Metode Penelitian Pendidikan. Bandung: Remaja Rosdakarya, 2013. 